\title{
Analisis Pola Konsumsi dan Tingkat Kerawanan Pangan Petani Lahan Kering di Kabupaten Gunungkidul (Studi Kasus di Desa Giritirto, Kecamatan Purwosari, Gunungkidul)
}

D 0 I:10.18196/ agr.2237

\begin{abstract}
Gunungkidul was being as an extreme nature and categorized as marginal land which was cause food shortages in some districts. One of the district experienced food shortages in 2013 was Purwosari. This research aimed to find out the food consumption patterns and relation among land area, income and educational levels of the dry land farmers toward the food shortages level. The research method used in this study was descriptive technique by giving explanation from statistic data (percentage, mean, data range, frequency distribution, cross tabulation). Moreover, in order to measure the food shortages leve this study used the comparison formula between the number of poor people consuming food with the nutrition daily value as much as 2,150 calories. The research findings show that the
\end{abstract}

average daily individual consumption was $1274.25 \mathrm{Kkal}$, and categorized as people who are extremely food shortages. The calories are mostly gained from consuming rice, corn and tempe, as daily consumption patterns. The levels of farmers' income, farming land areas, and level of education are not related to the food shortages level.

Keywords: dry land, food consumption pattern, food shortages

\section{INTISARI}

Kabupaten Gunungkidul dengan kondisi alam yang ekstrim dan masuk dalam kategori lahan marjinal, menyebabkan beberapa wilayah masuk dalam kategori rawan pangan. Salah satu Kecamatan yang masuk kategori rawan pangan pada tahun 2013 adalah Kecamatan Purwosari. Penelitian ini bertujuan untuk mengetahui tingkat kerawanan pangan; dan hubungan luas lahan, pendapatan dan tingkat pendidikan terhadap tingkat kerawanan pangan. Metode penelitian dilakukan menggunakan teknik deskriptif dengan memberikan penjelasan dari statistik data (percentage, mean, data range, frequency distribution, cross tabulation) dan untuk mengukur tingkat kerawanan pangan dengan menggunakan rumus perbandingan antara jumlah penduduk miskin yang mengkonsumsi pangan dengan angka kecukupan gizi sebesar 2.100 kalori. Hasil penelitian menyimpulkan bahwa rata-rata konsumsi kalori harian individu adalah sebesar 1274.25 kalori, dan termasuk dalam kategori penduduk sangat rawan pangan. Kalori tersebut sebagian besar diperoleh dari konsumsi beras, jagung dan tempe, sehingga hal tersebut menjadi pola konsumsi harian. Tingkat pendapatan petani, luas lahan pertanian dan tingkat pendidikan tidak memiliki hubungan dengan tingkat kerawanan pangan.

Kata kunci: kerawanan pangan, lahan kering, pola konsumsi pangan

\section{PENDAHULUAN}

Undang Undang Pangan No. 18 tahun 2012 Pasal 2 menyebutkan 
bahwa prinsip atau asas penyelenggaraan pangan di Indonesia harus berdasarkan kedaulatan, kemandirian, ketahanan, keamanan, manfaat, pemerataan, berkelanjutan, dan keadilan. Ketahanan pangan adalah keadaan terpenuhinya kebutuhan pangan yang tersedia setiap waktu, mudah didapatkan, aman dikonsumsi dengan harga yang terjangkau. Terkait dengan definisi tersebut maka komponen dari ketahanan pangan adalah i) ketersediaan pangan, ii) distribusi dan konsumsi pangan, iii) kemudahan didapatkan, iv) diversifikasi pangan, dan v) keamanan dikonsumsi (Mallisa, 2013)

Tingginya tingkat pertumbuhan penduduk di Indonesia, yang saat ini mencapai 230 juta, berbanding lurus dengan meningkatnya kebutuhan pangan. Di sisi lain, produksi pangan memiliki ketergantungan alamiah terhadap alam, yang akibatnya pangan tertentu hanya dapat dihasilkan pada kondisi alam tertentu pula. Oleh karena itu, daerah tertentu memiliki potensi produksi untuk jenis pangan tertentu.

Kerawanan pangan dan kemiskinan hingga kini masih menjadi masalah utama di Indonesia. Kerawanan pangan mempunyai korelasi positif dan erat kaitannya dengan kemiskinan. Data BPS (2016) menjelaskan bahwa pada bulan September 2015 jumlah penduduk miskin (penduduk dengan pengeluaran per kapita per bulan di bawah garis kemiskinan) di Indonesia mencapai 28,51 juta orang (11,13\%); berkurang sebesar 0,08 juta orang dibandingkan dengan kondisi Maret 2015 yang berjumlah 28,59 juta orang (11,22\%).

Hasil penelitian Mardiana (2009) bahwa pendapatan, pendidikan dan kepemilikan aset produktif berpengaruh terhadap kerawanan pangan rumah tangga miskin di Desa Wiru Kecamatan Bringin Kabupaten Semarang. Hasil penelitian tersebut menguatkan bahwa kemiskinan merupakan pangkal terjadinya kerawanan pangan.

Konsumsi makanan penduduk miskin pada umumnya rendah dan zat gizinya juga rendah, sehingga daya tahan tubuh taraf kesehatan umumnya rendah akibatnya produktivitas kerja rendah dan akhirnya tingkat pendapatan rendah. Dalam keadaan demikian, kegiatankegiatan yang timbul secara berurutan dapat mengakibatkan tingkat konsumsi makanan menurun sehingga disebut rawan pangan.

Pencegahan rawan pangan dapat dilakukan melalui pendekatan pengembangan sistem kewaspadaan pangan dan gizi (SKPG) dengan melaksanakan 3 kegiatan berikut, yakni: i) peramalan situasi pangan dan gizi, termasuk peramalan ketersediaan pangan dan pemantauan pertumbuhan balita dan hasil pengamatan sosial ekonomi; ii) kajian situasi pangan dan gizi secara berkala berdasarkan hasil survei khusus atau dari laporan tahunan; iii) diseminasi hasil peramalan dan kajian situasi pangan dan gizi bagi perumus kebijakan (forum koordinasi tingkat desa, kecamatan, kabupaten dan provinsi).

Kabupaten Gunungkidul merupakan kabupaten paling selatan dan memiliki luas 1.485,36 $\mathrm{km}^{2}$ atau 46, 63\% dari total wilayah Propinsi Daerah Istimewa Yogyakarta. Daerah ini mempunyai topografi berupa pegunungan kapur yang terbentang dari barat sampai timur. Topografi tersebut berpengaruh pada jenis penggunaan lahan di Kabupaten Gunungkidul. Kondisi tanah yang tidak begitu subur dan diperberat dengan permasalahan ketersediaan air menjadikan daerah ini termasuk daerah miskin dengan pendapatan perkapita 3,2 juta rupiah. Hal tersebut terjadi karena 70\% dari penduduk Kabupaten Gunungkidul adalah petani gurem dengan berbagai keterbatasan baik dari alam, teknologi dan modal.

Berdasarkan data dari BPS Kabupaten Gunungkidul (2014) sebagian besar (95\%) lahan pertanian di Kabupaten Gunungkidul adalah lahan kering, dan hanya $5 \%$ saja yang berupa lahan sawah 5\%. Kondisi alam yang ekstrim dan masuk dalam kategori lahan marjinal, menyebabkan beberapa wilayah di Kabupaten Gunungkidul masuk dalam kategori rawan pangan. Kecamatan yang masuk kategori rawan pangan pada tahun 2013 adalah Kecamatan Purwosari, Paliyan dan Girisubo.

Berbagai upaya telah dilakukan oleh pemerintah guna mengantisipasi kerawanan pangan, salah satunya adalah dengan peningkatan pendapatan usahatani. Faktor lain yang dimungkinkan berpengaruh terhadap kerawanan pangan di daerah setempat adalah luas lahan pertanian dan pendidikan. Berdasarkan latar belakang tersebut perlu dilakukan kajian terkait dengan tingkat kerawanan pangan dan hubungan antara pendapatan, luas lahan dan pendidikan dengan kerawanan pangan.

\section{METODE PENELITIAN}

Metode dasar yang digunakan dalam penelitian ini adalah metode deskriptif analitis dengan memusatkan perhatian pada masalah-masalah yang terjadi terkait dengan kerawanan pangan. Prosesnya adalah data yang telah dikumpulkan, disusun, dijelaskan dan kemudian dianalisis (Surakhmad et. al., 1985). Lokasi penelitian yaitu Desa Giritirto, Kecamatan Purwosari, Kabupaten 
Gunungkidul, Propinsi Daerah Istimewa Yogyakarta termasuk desa rawan pangan di Kabupaten Gunungkidul yang memiliki potensi untuk pengembangan tanaman jagung dan padi gogo. Data dikumpulkan dari petani penggarap lahan kering yang termasuk dalam kategori keluarga rawan pangan. Desa Giritirto memiliki 7 pedukuhan, dari setiap pedukuhan diambil secara random 10 petani sebagai sampel, sehingga secara keseluruhan terdapat 70 petani sampel.

Data dianalisis secara deskriptif dengan memberikan penjelasan data statistik yang meliputi percentage, mean, data range, frequency distribution, cross tabulation; sedangkan untuk mengukur tingkat kerawanan pangan digunakan rumus perbandingan antara konsumsi pangan dengan angka kecukupan gizi (AKG) sebesar 2.150 kalori. Peraturan Menteri Kesehatan Republik Indonesia Nomor 75 Tahun 2013) mengkatagorikan penduduk dalam: i) penduduk sangat rawan, jika konsumsi kurang dari 70\% AKG; ii) penduduk pangan resiko sedang, jika konsumsi 70 - 89,9\% AKG; iii) penduduk tahan pangan, jika konsumsi lebih dari 89,9\% AKG. Selanjutnya, hubungan antara tingkat kerawanan pangan dengan tingkat pendapatan, luas lahan dan tingkat pendidikan dianalisis menggunakan tabulasi silang.

\section{HASIL DAN PEMBAHASAN}

Pangan merupakan salah satu kebutuhan pokok yang diiringi kebutuhan pokok lain yaitu sandang dan papan. Ketiga kebutuhan tersebut harus terpenuhi agar hidup dapat seimbang. Jenis bahan pangan yang paling dicari di Indonesia adalah beras atau nasi sebagai makanan pokok dan berbagai jenis lauk pauk baik dari nabati ataupun hewani. Indonesia masih memiliki lahan sawah yang luas untuk ditanami padi sebagai bahan pangan pokok.

Namun, Indonesia belum dapat memenuhi kebutuhan pangan warganya, sehingga masih memerlukan impor beras dari luar negeri. Maka tidak heran jika harga beras dapat melambung tinggi, sehingga tidak terjangkau oleh kalangan bawah yang membuat kalangan ini sulit untuk memenuhi kebutuhan bahan pangan pokok dan kebutuhan kalori sebanyak 2.150 AKG setiap harinya. Kondisi ini menyebabkan suatu daerah dapat disebut masuk dalam kategori rawan pangan. Pada penelitian ini akan dibahas mengenai tingkat kerawanan pangan dan faktor yang mempengaruhi kerawanan pangan di Desa Girirtirto, Kecamatan Purwosari, Kabupaten Gunung Kidul.

\section{POLA KONSUMSI}

Selayaknya di wilayah Indonesia lainnya, penduduk di Desa Giritirto mengkonsumsi nasi sebagai bahan pangan pokok. Namun, dari 70 penduduk yang menjadi responden terdapat beberapa sampel yang menambahkan konsumsi jagung dan ketela untuk memenuhi kebutuhan karbohidrat, walau tidak menjadi makanan yang dikonsumsi setiap hari. Nasi yang dikonsumsi berasal dari pertanian di lahan sendiri, karena hampir semua petani menanam padi, baik padi di lahan sawah atau pun padi gogo di lahan tegalan. Prduksi yang dihasilkan tidak hanya digunakan untuk konsumsi sendiri, namun juga dijual untuk memenuhi kebutuhan lainnya. Biasanya padi yang tidak dijual disimpan di lumbung mandiri yang terdapat di rumah masing-masing petani. Jagung dan ketela yang digunakan untuk tambahan beras, juga merupakan hasil pertanian di lahan sendiri. Berikut adalah tabel konsumsi penduduk Giritirto selama satu tahun dengan rata-rata anggota keluarga sebanyak 4 orang.

TABEL I. KONSUMSI KALORI RATA-RATA I KELUARGA DALAMI TAHUN

\begin{tabular}{llll}
\hline Jenis Makanan & $\begin{array}{l}\text { Berat } \\
(\mathrm{Kg})\end{array}$ & $\begin{array}{l}\text { Kalori Harian } \\
\text { Per Keluarga }\end{array}$ & $\begin{array}{l}\text { Kalori harian } \\
\text { Individu }\end{array}$ \\
\hline Beras & 422 & 2021 & 505,25 \\
Jagung & 48 & 474 & 118,5 \\
Ketela & 50 & 200 & 50 \\
Tahu & 37 & 114 & 28,5 \\
Tempe & 297 & 1918 & 479,5 \\
Ikan & 6 & 20 & 5 \\
Telur & 31 & 138 & 34,5 \\
Kangkung & 56 & 69 & 17,25 \\
Gula & 14 & 143 & 35,75 \\
Kopi & 10 & 0 & 0 \\
Teh & 16 & 0 & 0 \\
\hline
\end{tabular}

Dari Tabel 1 dapat dilihat bahwa rata-rata 1 keluarga yang beranggotakan 4 orang mengkonsumsi $422 \mathrm{~kg}$ beras dalam 1 tahun. Tidak hanya karbohidrat, protein juga merupakan kandungan yang perlu diperhatikan dalam mengkonsumsi makanan, baik protein hewani atau nabati. Sebagaimana orang Indonesia pada umumnya, penduduk Giritirto juga mengkonsumi tahu dan tempe untuk memenuhi protein nabati. Selain murah dan mudah didapatkan, tahu dan tempe memiliki kandungan protein yang baik untuk tubuh dan rendah lemak, 
sehingga aman dikonsumsi segala usia. Satu keluarga di Giritirto dengan rata-rata 4 anggota keluarga mengkonsumsi $37 \mathrm{~kg}$ tahu dan $297 \mathrm{~kg}$ tempe. Kemudahan mencampurkan tempe ke dalam berbagai jenis masakan mengakibatkan konsumsi tempe lebih banyak daripada tahu.

Berbeda halnya dengan konsumsi protein hewani yang jauh lebih rendah, khususnya konsumsi ikan. Konsumsi protein hewani dihitung dari konsumsi ikan lele dan telur ayam yang harganya lebih terjangkau dan mudah untuk mendapatkannya, baik di pasar tradisional maupun toko kelontong. Keluarga di Giritirto yang memiliki 4 anggota keluarga rata-rata hanya mengkonsumsi $6 \mathrm{~kg}$ ikan per tahunnya, sedangkan untuk konsumsi telur hanya 31 $\mathrm{kg}$ pertahun. Konsumsi protein hewani dan nabati menjadi tidak seimbang, karena konsumsi protein nabati yang tinggi dan berbanding terbalik dengan konsumsi protein hewani. Kebutuhan serat dan vitamin dipenuhi dari konsumsi kangkung sebanyak 56 kg per keluarga per tahun. Kurangnya asupan protein hewani dapat mempengaruhi perhitungan kalori harian setiap individu. Pola konsumsi yang masih disamakan dengan budaya masa lalu dapat mempengaruhi kekurangan asupan kalori.

\section{TINGKAT KERAWANAN PANGAN}

Kalori dibutuhkan oleh tubuh untuk menghasilkan energi yang digunakan untuk beraktivitas sehari-hari. Standar kalori yang dibutuhkan oleh orang dewasa setiap harinya adalah $2150 \mathrm{Kkal}$. Tidak terpenuhinya kebutuhan kalori mengakibatkan kekurangan energi dalam tubuh yang dapat mengganggu aktivitas. Dalam penelitian ini, tingkat kerawanan dan faktor-faktor yang diduga mempengaruhinya dianalisis menggunakan tabulasi silang. Tingkat kerawanan pangan dibagi menjadi 3 katagori, yaitu sangat rawan pangan dengan tingkat konsumsi $<70 \%$ AKG, pangan resiko sedang dengan tingkat konsumsi 70-89,9\% AKG, serta tahan pangan dengan tingkat konsumsi > 89,9\% AKG. Penduduk di Desa Giritirto sebagian besar termasuk dalam katagori sangat rawan pangan $(67,1 \%)$, hanya terdapat 13 orang atau $18,6 \%$ penduduk yang masuk dalam kategori tahan pangan (Tabel2).
TABEL 2. TINGKat KERAWANAN PANGAN PENDUDUK DESA GIRITIRTO

\begin{tabular}{lcc}
\hline Tingkat Kerawanan Pangan & Total & Persentase \\
\hline $\begin{array}{l}\text { Penduduk Sangat Rawan Pangan } \\
(<1400 \text { Kkal })\end{array}$ & 47 & $67,1 \%$ \\
$\begin{array}{l}\text { Penduduk Pangan Resiko Sedang } \\
(1400-1.798 \text { Kkal })\end{array}$ & 10 & $14,3 \%$ \\
$\begin{array}{l}\text { Penduduk Tahan Pangan } \\
(>1798 \text { Kkal })\end{array}$ & 13 & $18,6 \%$ \\
\hline Total & 70 & $100,0 \%$ \\
\hline
\end{tabular}

\section{HUBUNGAN TINGKAT KERAWANAN PANGAN DENGAN TINGKAT PENDAPATAN}

Pendapatan total bersumber dari pendapatan on farm dan pendapatan off farm. Pendapatan on farm didapatkan dari lahan pertanian dengan berbagai jenis tanaman, sedangkan pendapatan off farm didapatkan dari luar lahan pertanian seperti pegawai atau karyawan, buruh tani, buruh bukan tani dan pedagang. Data pada Tabel 3 menunjukkan petani yang berpendapatan tinggi lebih banyak (40\%) dari pada petani berpendapatan sedang (28\%) maupun berpendapatan rendah (31\%).

TABEL 3. TINGKAT PENDAPATAN PETANI GIRITIRTO (RP/TAHUN)

\begin{tabular}{lllll}
\hline No & Pendapatan (.000) & Jumlah & 6) & Kategori \\
\hline 1 & $1.000-2.500$ & 12 & 7,14 & Rendah \\
2 & $2.500-5.000$ & 10 & 1,29 & Rendah \\
3 & $5.000-10.000$ & 16 & 2,87 & Sedang \\
4 & $10.000-15.000$ & 4 & 70 & Sedang \\
5 & $15.000-25.000$ & 14 & 3,00 & Tinggi \\
6 & $25.000-35.000$ & 10 & 1,28 & Tinggi \\
7 & $35.000-60.000$ & 4 & 72 & Tinggi \\
\hline
\end{tabular}

Pendapatan responden berkisar antara Rp1.122.167 sampai Rp54.656.667 dengan distribusi sebagaimana ditunjukkan pada Tabel 3. Kesenjangan pendapatan responden yang cukup tinggi disebabkan perbedaan penguasaan luas lahan produktif pertanian dengan hasil panennya dan adanya pendapatan off farm. Kontribusi pendapatan usahatani diperoleh dari komoditas padi, jagung dan kacang tanah di musim hujan dan kemarau, dengan jenis lahan sawah tadah hujan dan tegalan. Padi yang menjadi komoditas utama pada musim hujan, mampu menghasilkan pendapatan sebesar Rp1.443.000 untuk lahan sawah, sedangkan untuk lahan tegalan 


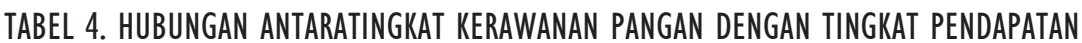

\begin{tabular}{llccccc}
\hline \multirow{2}{*}{ Tingkat Kerawanan Pangan } & \multicolumn{2}{c}{ Pendapatan } & & & \\
& Rendah & $\%$ & Sedang & $\%$ & Tinggi & $\%$ \\
\hline Penduduk Sangat Rawan Pangan & 10 & $14,3 \%$ & 12 & $17,1 \%$ & 25 & $35,7 \%$ \\
Penduduk Pangan Resiko Sedang & 7 & $10,0 \%$ & 1 & $1,4 \%$ & 2 & $2,9 \%$ \\
Penduduk Tahan Pangan & 5 & $7,1 \%$ & 7 & $10,0 \%$ & 1 & $1,4 \%$ \\
Total & 22 & $31,4 \%$ & 20 & $28,6 \%$ & 28 & $40,0 \%$ \\
\hline
\end{tabular}

hanya sebesar Rp622.850 dengan luas lahan 0,1 ha.

Komoditas dominan kedua adalah tanaman jagung, yang diusahakan baik pada musim hujan maupun musim kemarau. Rata-rata pendapatan usahatani jagung pada musim hujan di lahan tegal adalah sebesar Rp286.175 per 0,1 ha. Komoditas jagung pada musim kemarau diusahakan pada lahan sawah tadah hujan dan tegalan dan mampu menghasilkan pendapatan masing-masing sebesar Rp346.550 dan Rp1.273.100. Kacang tanah termasuk tanaman primadona masyarakat di Desa Giritirto dan diusahakan pada musim kemarau. Pendapatan yang mampu dihasilkan cukup tinggi yaitu Rp1.157.000 per 0,1 ha. Berdasarkan pendapatan usahatani tersebut maka dapat disimpulkan bahwa kontribusi pendapatan usahatani terhadap pendapatan total rumah tangga responden adalah sebesar $47 \%$, sedangkan 53\% pendapatan keluarga di peroleh dari pendapatan off farm seperti pegawai atau karyawan, buruh tani, buruh bukan tani, pedagang dan kiriman dari keluarga yang bekerja di luar daerah.

Dari Tabel 4 dapat dilihat bahwa penduduk yang paling banyak masuk dalam kategori penduduk sangat rawan adalah penduduk dengan pendapatan yang tinggi sejumlah 25 orang atau 35,7\%. Penduduk sangat rawan pangan yaitu penduduk yang hanya mengkonsumsi kalori $<70 \%$ AKG setiap hari. Terdapat sebanyak 13 sampel penduduk yang masuk dalam kategori tahan pangan, dan hanya satu yang memiliki pendapatan kategori tinggi atau hanya sebesar $1,4 \%$. Penduduk tahan pangan yaitu penduduk yang dapat memenuhi kebutuhan kalori harian mencapai $>89,9 \%$ AKG. Data ini menunjukkan bahwa tingkat pendapatan tidak berpengaruh terhadap kemampuan pemenuhan kebutuhan kalori harian.

Faktor lain yang dapat mempengaruhi masyarakat masuk ke dalam kategori sangat rawan pangan adalah pola konsumsi masyarakat yang kurang memperhatikan nilai gizi dan sudah menjadi kebiasan dari dulu. Kebiasaan yang dimaksud adalah kebiasaan menerapkan sistem asal kenyang tanpa memperhatikan kandungan apa yang ada di dalam makanan tersebut seperti karbohidrat, protein, vitamin dan mineralnya sehingga mengakibatkan kurangnya kalori dalam tubuh. Faktor lain yang dapat mempengaruhi, yaitu faktor pendidikan melihat 39 orang atau sebanyak $55,7 \%$ sampel petani merupakan lulusan sekolah dasar sehingga tidak begitu memahami apa itu kandungan dalam makanan ataupun kalori. Dari Tabel 4 dapat disimpulkan bahwa di Desa Girikerto kecenderungan rawan pangan terjadi pada semua tingkat pendapatan (rendah, sedang, tinggi).

\section{HUBUNGAN TINGKAT KERAWANAN PANGAN DENGAN LUAS LAHAN}

Terdapat 3 jenis lahan yang ditanami di Desa Giritirto, yaitu sawah, tegalan dan pekarangan yang masing masing memiliki jenis tanaman yang berbeda. Jenis tanaman yang ditanam di lahan sawah pada musim hujan adalah padi yang ditanam oleh hampir semua responden. Lahan tegalan ditanami beberapa jenis tanaman yaitu jagung dan kacang tanah. Luas lahan pada Tabel 5 merupakan luas lahan pertanian produktif yaitu lahan yang mampu berproduksi untuk usahatani tanaman pangan dan lainnya seperti padi, jagung dan kacang tanah.

\section{TABEL 5. DISTRIBUSI LUAS LaHAN PERTANIAN (SAWAH DAN TEGAL)}

\begin{tabular}{lllll}
\hline No & Luas Lahan (Ha) & Jumlah & Persentase & Kategori \\
\hline 1 & $0,025-0,1$ & 18 & 25,71 & Sempit \\
2 & $0,1-0,25$ & 20 & 28,57 & Sempit \\
3 & $0,25-0,5$ & 15 & 21,43 & Sedang \\
4 & $0,5-1$ & 10 & 14,29 & Luas \\
5 & $1-5$ & 7 & 10,00 & Luas \\
\hline
\end{tabular}

Hasil observasi menginformasikan bahwa responden juga memiliki lahan pekarangan atau lahan kering, berbatu namun karena tidak memungkinkan untuk usahatani tanaman pangan maka tidak dimasukan 
TABEL 6. HUBUNGAN KALORI DENGAN LUAS LAHAN YANG DIMILIKI

\begin{tabular}{lllllll}
\hline \multirow{2}{*}{ Tingkat Kerawanan Pangan } & \multicolumn{2}{l}{ Luas Lahan } \\
\cline { 2 - 7 } & Sempit & $\%$ & Sedang & $\%$ & Luas & $\%$ \\
\hline Penduduk Sangat Rawan Pangan & 21 & $30,0 \%$ & 11 & $15,7 \%$ & 15 & $21,4 \%$ \\
Penduduk Pangan Resiko Sedang & 7 & $10,0 \%$ & 1 & $1,4 \%$ & 2 & $2,9 \%$ \\
Penduduk Tahan Pangan & 10 & $14,3 \%$ & 3 & $4,3 \%$ & 0 & $0 \%$ \\
\hline Total & 38 & $54,3 \%$ & 15 & $21,4 \%$ & 17 & $24,3 \%$ \\
\hline
\end{tabular}

TABEL 8. HUBUNGANTINGKAT KERAWANAN PANGAN DENGAN TINGKAT PENDIDIKAN

\begin{tabular}{lllllll}
\hline \multirow{2}{*}{ Tingkat Kerawanan Pangan } & \multicolumn{7}{l}{ Pendidikan } \\
\cline { 2 - 7 } & \multicolumn{1}{l}{ Rendah $\%$} & \multicolumn{1}{l}{ Menengah } & $\%$ & Tinggi & $\%$ \\
\hline Penduduk Sangat Rawan Pangan & 22 & $31,4 \%$ & 25 & $35,7 \%$ & 0 & $0 \%$ \\
Penduduk Pangan Resiko Sedang & 5 & $7,1 \%$ & 4 & $5,7 \%$ & 1 & $1,4 \%$ \\
Penduduk Tahan Pangan & 12 & $17,1 \%$ & 1 & $1,4 \%$ & 0 & $0 \%$ \\
\hline Total & 39 & $55,7 \%$ & 30 & $42,9 \%$ & 1 & $1,4 \%$ \\
\hline
\end{tabular}

sebagai lahan produktif dalam analisis ini. Rata-rata luas lahan untuk tanaman padi adalah 0,25 ha dan diusahakan pada musim hujan, sedangkan lahan tegal banyak diusahakan pada musim kemarau dengan komoditas jagung dengan rata-rata luas lahan 0,2 ha. Rata-rata produktivitas padi adalah 1,2 ton per hektar dan rendahnya produktivitas berpengaruh terhadap pendapatan usahatani padi. Tabel 6 menampilkan hasil tabulasi silang antara luas lahan, sebagai sumber pendapatan on farm dengan tingkat kerawanan pangan.

Dari Tabel 6 dapat dilihat bahwa sebagian besar penduduk sangat rawan pangan (30\%) merupakan penduduk yang memiliki lahan sempit. Penduduk yang memiliki lahan sempit akan memiliki pendapatan on farm yang kurang jika dibandingkan dengan penduduk yang memiliki lahan yang luas sehingga berpengaruh pada pendapatan total. Walaupun luas lahan berpengaruh pada pendapatan total, namun pendapatan total tidak berpengaruh pada tingkat kerawanan pangan. Luas lahan juga tidak ada hubungannya dengan kerawanan pangan, karena tidak ada sampel petani dengan lahan yang luas masuk dalam kategori penduduk tahan pangan. Bahkan sebaliknya, terdapat sebanyak 10 orang atau $14,3 \%$ sampel petani yang memiliki lahan sempit namun masuk dalam kategori penduduk tahan pangan. Berdasarkan hasil analisis tersebut dapat disimpulkan bahwa tidak ada hubungan antara luas lahan dengan tingkat kerawanan pangan.

\section{HUBUNGAN TINGKAT KERAWANAN PANGAN DENGAN TINGKAT PENDIDIKAN}

Pendidikan merupakan bekal yang harus diberikan semenjak kecil. Namun orang zaman dahulu masih belum terlalu memperhatikan pendidikan sehingga setelah dewasa mereka merasa kurang memiliki bekal pendidikan sehingga cukup sulit untuk menghadapi kehidupan di masa sekarang yang serba menggunakan teknologi canggih. Sama halnya dengan penduduk sampel di Desa Giritirto, masih banyak yang hanya lulusan sekolah dasar sehingga mempersempit pengetahuan mereka khususnya pengetahuan mengenai nilai gizi. Pada penelitian ini, pendidikan dibagi dalam 3 tingkatan: tingkat pertama atau rendah, yaitu penduduk yang tidak bersekolah atau hanya lulus sekolah dasar; tingkat kedua atau menengah, yaitu penduduk yang lulus sekolah menengah baik sekolah menengah pertama atau kedua; dan tingkat ketiga, yaitu penduduk yang lulus perguruan tinggi.

\section{TABEL 7. DISTRIBUSI TINGKAT PENDIDIKAN PETANI DESA GIRITIRTO}

\begin{tabular}{lllll}
\hline No & Tingkat Pendidikan & \multicolumn{2}{l}{ Jumlah \% } & Kategori \\
\hline 1 & Tidak Lulus SD & 4 & 5.71 & Rendah \\
2 & Tamat SD & 35 & 50.00 & Rendah \\
3 & Tamat SMP & 17 & 24.29 & Menengah \\
4 & Tamat SMA & 13 & 18.57 & Menengah \\
5 & Perguruan Tinggi (D3) & 1 & 1.43 & Tinggi \\
\hline
\end{tabular}


Tabel 7 menginformasikan bahwa secara umum petani di desa Giritirto memiliki tingkat pendidikan yang cukup baik. Hal tersebut dapat dilihat bahwa hanya ada 4 petani yang belum tamat sekolah dasar (SD) dan sejumlah 35 petani sudah tamat SD sehingga dapat dipastikan sudah mampu membaca dan menulis. Lebih dari itu, sejumlah 30 petani sudah mampu tamat di tingkat sekolah menengah baik sekolah menengah pertama (SMP) maupun sekolah menengah atas (SMA). Tabel 7 juga mampu menjelaskan bahwa sudah ada 1 petani yang sudah melanjutkan di level perguruan tinggi baik (D3). Analisis hubungan tingkat kerawanan pangan dengan tingkat pendidikan ditampilkan pada Tabel 8 .

Tabel 8 menunjukkan bahwa dari total 47 orang penduduk sangat rawan pangan, sebanyak 22 orang merupakan penduduk yang lulus sekolah dasar dan sisanya atau 25 orang merupakan penduduk yang lulus pada tingkat sekolah menengah. Terlihat dari Tabel 8 bahwa sejumlah 22 petani yang masuk dalam kategori sangat rawan pangan adalah penduduk yang memiliki pendidikan dasar atau hanya lulus sekolah dasar. Penduduk yang merupakan lulusan sekolah dasar memiliki pengetahuan yang kurang terhadap pemenuhan gizi harian sehingga mengakibatkan kalori yang dikonsumsi tidak memenuhi standar AKG. Selain itu, mereka juga memiliki pemikiran yang masih tertutup sehingga kurang dapat menerima perubahan zaman seperti sekarang. Mereka masih menerapkan budaya makan seperti pada saat mereka kecil yang memang pada zaman dahulu belum ada yang memperhitungkan mengenai kebutuhan kalori harian. Zaman yang sudah berubah belum bisa diterima oleh penduduk yang tidak memiliki pemikiran terbuka sehingga masih menerapkan budaya konsumsi zaman dahulu kepada anak-anaknya yang hidup di masa sekarang. Tabel 8 juga memperlihatkan bahwa kondisi rawan pangan juga dialami oleh para petani yang sudah memiliki tingkat pendidikan menengah. Kondisi tersebut cukup memprihatinkan karena seharusnya dari sisi pengetahuan mereka lebih paham terkait kebutuhan gizi keluarga. Kenyataan tersebut menyimpulkan bahwa tingkat pendidikan tidak berdampak pada pemenuhan gizi keluarga.

Berdasarkan pada analisis maka dapat disimpulkan bahwa penduduk Desa Giritirto masuk dalam kategori sangat rawan pangan. Hasil penelitian juga menunjukkan bahwa faktor tingkat pendapatan dan luas lahan tidak memiliki hubungan pada pemenuhan gizi keluarga yang akan berdampak pada tingkat kerawanan pangan. Terdapat beberapa faktor lain yang mempengaruhi tingkat kerawanan pangan, yaitu pola konsumsi yang diakibatkan karena budaya atau kebiasaan yang sudah berlangsung lama serta pendidikan yang kurang sehingga membuat pengetahuan menjadi kurang untuk memahami pentingnya pemenuhan kebutuhan kalori harian.

\section{KESIMPULAN}

Berdasarkan hasil penelitian dapat ditarik kesimpulan bahwa penduduk Desa Giritirto masuk dalam kategori sangat rawan pangan. Hasil penelitian juga menunjukkan bahwa faktor tingkat pendapatan dan luas lahan tidak memiliki hubungan pada pemenuhan gizi keluarga yang akan berdampak pada tingkat kerawanan pangan.

\section{DAFTAR PUSTAKA}

BPS Kabupaten Gunungkidul. 2014. Data Daerah Rawan Pangan 2013. Yogyakarta.

Choliq, A., Widarto, \& Susilo, J. 2004. Kajian Pertanian Lahan Kering di Kabupaten Blora. Yogyakarta.

Badan Ketahanan Pangan. 2015. Indikator Penanganan Daerah Rawan Pangan. BPS, Wonosobo. Diakses 6 April 2015. http:// ketahananpangan.wonosobo kab.go.id

Mallisa, V. 2013. Pola Konsumsi dan Ketahanan Pangan Rumah Tangga Tani di Kabupaten Jayawijaya. Disertasi, Universitas Gadjah Mada.

Badan Penelitian dan Pengembangan Pertanian. 2005. Ekonomi Padi dan Beras Indonesia. Pusat Pengembangan Ketersediaan Pangan Balitbang Pertanian, Jakarta.

Surakhmad, W., 1985. Pengantar Penelitian Ilmiah, Dasar Metode dan Teknik. Tarsitu, Bandung.

Mardiana, R. S. 2009. Faktor - Faktor yang Mempengaruhi Kerawanan Pangan Rumah Tangga Miskin di Desa Wiru, Kecamatan Bringin, Kabupaten Semarang. Skripsi, Universitas Negeri Semarang. 